\title{
Formation of requirements for human resources in the conditions of digital transformation of business
}

\author{
Anna M. Smirnova \\ Institute of Industrial Management, \\ Economics and Trade \\ Peter the Great Saint Petersburg \\ Polytechnic University \\ Saint Petersburg, Russia \\ smirnova_am@spbstu.ru
}

\author{
Iina M. Zaychenko \\ Institute of Industrial Management, \\ Economics and Trade \\ Peter the Great Saint Petersburg \\ Polytechnic University \\ Saint Petersburg, Russia \\ zaychenko@spbstu.ru
}

\author{
Irina V. Bagaeva \\ Institute of Industrial Management, \\ Economics and Trade \\ Peter the Great Saint Petersburg \\ Polytechnic University \\ Saint Petersburg, Russia \\ bagaeva_iv@spbstu.ru
}

\begin{abstract}
The article substantiates the need to revise the requirements for human resource management. On the one hand, this is due the development and implementation of ITtechnologies in almost all spheres of life in modern society that is a consequence of the development of Industry 4.0. And on the other hand, according to the program "Digital Economy of the Russian Federation" it is one of the priority directions for the implementation of this program. At the same time, the development of a competent employee model is one of the main trends of the modern human resource management system. A comparative analysis of the classical and modern personnel management systems made it possible to identify and describe the main trends in human resource management in the context of digital business transformation, as well as to identify the main problems in their implementation. The result of the work was a formulated system of requirements for a modern employee, here are the main: emotional intelligence; systemic, flexible thinking; teamwork skills; skills related to the application of ITtechnologies in everyday and professional activities, interdisciplinary knowledge and others. It was also found that the proposed system of requirements for an employee is currently not being implemented and it is necessary to implement additional training programs, including through the introduction of digital technologies, the use of chat bots may be a priority for solving this probleml.
\end{abstract}

Keywords-digital economy, digital business transformation, human resource management, trends in human resource management in a digital economy, the formation of personnel requirements in a digital transformation

\section{INTRODUCTION}

The transition of the traditional economy to a digital one caused by the rapid pace of ongoing changes in the socioeconomic sphere, the emergence of both new challenges and dangers but also new opportunities for doing business require the development of new conceptual approaches to making management decisions. Only in a similar way it is possible to counteract the latest challenges, adequately take into account new dangers and take advantage of new opportunities.

The prerequisites for the speedy transition to digital business management are:

- the need to explore the distinctive features of Industry 4.0 in the context of the evolution of the formation of an industrial society;

- identification of new drivers of formation of requirements for human resource management in the enterprise in the conditions of digital transformation of society.

In our country, the digitalization of the social and economic life of society has become increasingly common after the Russian government approves the Digital Economy program [1] which describes the digital transformation of such areas as education and personnel, cybersecurity, the formation of research competencies, regulation and IT infrastructure. However, the program itself means only the directions in which it is necessary to move and develop, and specific measures are fixed in the development strategies for each direction. So, in the direction of "digital technology" the main objectives are to achieve the following indicators [2]: 30 implemented projects in the field of the digital economy; 10 Russian organizations involved in the implementation of large projects in priority areas of international scientific and technical cooperation in the field of the digital economy. The technologies that the state program wants to develop include: big data; Artificial Intelligence; new production technologies; industrial Internet; virtual and additional reality technologies; components of robotics and sensorics, and others.

One of the main directions of the successful implementation of the Digital Economy program is "personnel for the digital economy". Human resource management is one of the main parameters for ensuring the competitiveness of enterprises in modern conditions. According to this program, the formation of "personnel for the digital economy" begins with implying the improvement of the education system, which should provide the digital economy with personnel with the necessary competencies in Industry 4.0. The next important aspect is the transformation of the labor market, which consists of the speedy restructuring of traditional personnel requirements that ensure the availability of modern digital competencies. And the last aspect is the creation of a personnel motivation system for mastering the necessary competencies and personnel participation in the development of the digital economy of the Russian Federation.

Thus, the resulting changes require a global review of the requirements for the formation of a system of human resource management in the enterprise and the development of radically new approaches to creating a competent model of a modern employee.

In the period of development of information technologies that penetrate all the business processes of modern enterprises, 
it is difficult to circumvent such a thing as digitalization. Almost every business process can be improved with the help of digital technologies, there are many platforms, services and IT solutions on the market that significantly simplify the management of the business in general and the performance of the functional duties of a particular employee. As for personnel management, if earlier the HR-specialist was unequivocally related to the humanitarian professions, now it becomes work for systemic people who understand the logic of processes and technologies and also know how to build new technological solutions. With the help of digital tools a specialist can streamline processes, conduct analytics and build forecasts. These tools allow you to simplify, for example, the work of recruiters, for instance, using chat bots or to organize the process of online training, certification.

\section{LITERATURE REVIEW}

Currently, a huge amount of work has appeared in the literature [3-12]. Dedicated to the issues of digital business transformation. Part of them $[10,12]$ provide a detailed description and analysis of digital transformation tools, some describe the general concept of forming an enterprise architecture [11], some [4] use IT services. In addition, the proposed and many industry-specific digital solutions. So, [13] - in building, [14,15] - in mining, [16,17] - in the financial sector. As for the sphere of personnel management and the proposal of digital solutions for its improvement, we can distinguish the work [18-25]. Despite the fact of the appearance of works describing the introduction of IT technologies in the field of human resource management in this area, the works [26-27] still prevails, reflecting the classical concept of human resource management in the enterprise, including in the context of the formation of personnel requirements.

Thus, the development of a system of personnel requirements in a digital economy is one of the key elements of building a modern personnel management system.

For the first time, the formation of a competence-based approach to human resource management is mentioned in [28] Robert White formulates the definition of competence as effective interaction with the environment ("under the general heading of competence"). In the following years, a number of eminent psychologists dealt with the subject of competencies: Chris Argyris, Richard E. Boyatzis, George O. Klemp, Jr., Lyle M. Spencer, Jr. other. In their work, they explore a wide range of competencies, including working competencies, interpersonal competencies, and managerial competencies, studying the influence of competencies on the effectiveness and efficiency of employees of organizations. For two decades of research, they and many others have identified many different competencies and created comprehensive competence models of workers. So, the author in [29] identifies the following systemic competences of an employee:

- Instrumental - cognitive abilities, methodological abilities, technological abilities and linguistic abilities.

- Interpersonal - individual abilities as social skills (social interactions and cooperation).

- Systemic - abilities and skills related to whole systems (combining understanding, perception and knowledge; priority in acquiring the required instrumental and interpersonal competences).

An alternative competency models is proposed in [30,31]. For example, in [31], so a professional employee should have professional (professional-oriented), general (key, basic, universal, trans-subject, meta-professional, supraprofessional, nuclear) and academic competencies, etc.

However, these models can be relevant only in the framework of an agrarian or industrial society. Since, both in the agrarian (traditional economy) and in the industrial society (pre-industrial economy), man and his needs were at the center of the economic system.

The post-information society, the so-called Indstry 4.0, is characterized by the following processes: the person and information do not identify, artificial intelligence becomes the center of the economic system, capable of creating new knowledge by processing big data through self-learning machine learning systems, not just productivity, but adaptability to changing conditions that guarantee long-term competitiveness.

In a post-industrial society, intellectual capital included:

- human capital;

- organizational capital;

- information capital.

In the digital economy, intellectual capital is undergoing significant changes. Systems of artificial intelligence, the Internet of things, a cybernetic approach to business management replace and replace the components of intellectual capital described above.

The formation of a number of personnel requirements based on the employee's competency model is associated with the following problems:

- not all knowledge, skills and abilities that he possesses can be used in the immediate work activity of an employee;

- knowledge is relevant only for the current level of development of the economic system, it is necessary to constantly update and increase it to ensure the necessary level of personality development;

- the quality of knowledge is different; it is necessary that knowledge is not only relevant, but also actual.

Knowledge as a characteristic of cognitive and labor potential must be transformed into intellectual capital through professional competencies. It is worth noting that intellectual work and work with data is not the same thing. For the formation of professional competencies, a person needs a wide body of knowledge - not only scientific, but also socially determined (that is, everyday). According to the concept of $\mathrm{G}$. Gardner, [32] intelligence is a plural quantity. A person has several key types of intelligence that exist in different proportions for different people:

1. Abstract intelligence: symbolic thinking, abilities in the field of mathematics and formal logic.

2. Social intelligence: understanding of social contexts and adequate communication with people. 


\section{Practical intelligence: common sense.}

4. Emotional intelligence: self-awareness and selfgovernment.

5. Aesthetic intelligence: a sense of form, ability in design, music, art and literature.

6. Kinesthetic intelligence: physical skills.

At the same time, about $55 \%$ of the population of any country is not ready to develop their cognitive complex of knowledge and skills, to overcome development barriers to form themselves as a competitive specialist. And only $30 \%$ of the population is ready for self-development through the formation of professional competencies, and only $15 \%$ of the population is striving to form intellectual capital

\section{RESULTS}

Table 1 presents a comparison of classical approaches to human resource management and modern approaches based on digital business transformation.

Table 1 - Traditional and modern approaches to human resource management

\begin{tabular}{|c|c|}
\hline $\begin{array}{c}\text { Traditional HR Management } \\
\text { Approaches }\end{array}$ & $\begin{array}{l}\text { Approaches to HR manage- } \\
\text { ment in terms of digital busi- } \\
\text { ness transformation }\end{array}$ \\
\hline $\begin{array}{l}\text { HR focuses on designing pro- } \\
\text { cesses and harmonizing them } \\
\text { to create standard HR prac- } \\
\text { tices. }\end{array}$ & $\begin{array}{l}\text { HR departments focus on em- } \\
\text { ployee optimization, produc- } \\
\text { tivity, engagement, teamwork } \\
\text { and career growth. }\end{array}$ \\
\hline $\begin{array}{l}\text { HR selects cloud solutions and } \\
\text { implements non-standard } \\
\text { practices to create scale. }\end{array}$ & $\begin{array}{l}\text { HR develops innovative, com- } \\
\text { pany-specific programs, uses } \\
\text { applications and scaling plat- } \\
\text { forms. }\end{array}$ \\
\hline $\begin{array}{l}\text { Groups of HR-technologies } \\
\text { are focused on the implemen- } \\
\text { tation of ERP and integrated } \\
\text { analysis, with an emphasis on } \\
\text { "ease of use" }\end{array}$ & $\begin{array}{l}\text { HR technology goes beyond } \\
\text { ERP, developing digital capa- } \\
\text { bilities and mobile applica- } \\
\text { tions with a focus on "produc- } \\
\text { tivity" }\end{array}$ \\
\hline $\begin{array}{l}\text { HR departments focus on the } \\
\text { process design and improve- } \\
\text { ment process. }\end{array}$ & $\begin{array}{l}\text { Human resources departments } \\
\text { are increasingly using chat } \\
\text { rooms, applications and other } \\
\text { advanced technologies to ex- } \\
\text { pand the scale and capabilities } \\
\text { of employees. }\end{array}$ \\
\hline $\begin{array}{l}\text { HR programs are designed to } \\
\text { scale consistency around the } \\
\text { world. }\end{array}$ & $\begin{array}{l}\text { HR programs are focused on } \\
\text { employee segments, personali- } \\
\text { ties and specific groups, } \\
\text { providing them with a path re- } \\
\text { lated to their work and career }\end{array}$ \\
\hline $\begin{array}{l}\text { HR focuses on "self-service" } \\
\text { as a way to scale services and } \\
\text { support }\end{array}$ & $\begin{array}{l}\text { HR focuses on "creating op- } \\
\text { portunities" to help people do } \\
\text { work in a more efficient and } \\
\text { productive way. }\end{array}$ \\
\hline $\begin{array}{l}\text { The HR Department builds a } \\
\text { self-service portal for the em- } \\
\text { ployee as a technological plat- } \\
\text { form that makes it easy to find } \\
\text { operational needs and pro- } \\
\text { grams. }\end{array}$ & $\begin{array}{l}\text { HR-department builds an inte- } \\
\text { grated "employee experience } \\
\text { platform" using digital appli- } \\
\text { cations and bots to support the } \\
\text { current needs of employees }\end{array}$ \\
\hline
\end{tabular}

So, it can be stated that modern approaches to human resource management are based on teamwork as part of the implementation of a project approach to business management and should take into account both professional, including IT competencies, and personal aspects of the formation of a competent model of an individual employee in conditions.

Thus, it is possible to formulate the main trends in human resource management in a digital economy:

1. The use of artificial intelligence. Many programs, such as Siri, Alexa, Google Assistant, have successfully entered the daily lives of people, and are considered as potential assistants to HR specialists. Artificial intelligence is already being actively implemented abroad in the personnel management process, for example, the global giant Unilever uses this technology to select candidates for launch positions.

2. Online training. Increasingly, businesses are switching to online employee training platforms. This may apply to both external and internal training, which allows you to either turn to an external company with a ready-made solution for training specific competencies, or develop your own course for training directly to your organization's needs.

3. Using chat bots. Bots are increasingly gaining popularity among the automation of certain HR processes, such as answers to frequently asked questions or initial interviews with candidates for the position.

4. Gamification in management. In this case, it implies the use of triggers and other tools for motivation, adaptation and training of personnel. The use of technology with this approach is also possible and desirable. Usually in such cases, gaming platforms are developed and implemented with a simulation of the situation that needs to be studied. Or, if possible, an application is developed that is also gamified for a specific situation and necessary knowledge.

5. VR-technology as a tool for staff training. It is the technology of the future, but it is already used in some industrial companies to train employees. However, this is one of the most expensive ways, requiring large financial investments, both in the acquisition, development, and implementation in the overall learning process.

6. Use of online services for personnel management. There are many platforms and online services on the IT solutions market that are designed to solve daily tasks, automate HR processes, and create convenient, visual analytic reports.

7. Continuity of learning. When introducing technologies into processes, appropriate qualifications of personnel and continuous training are required to improve skills in the use of technology and web interfaces.

The development of these trends is impossible without the introduction of IT-technologies. Nevertheless, only a small proportion of HR managers use domestic enterprises to use these technologies (Figure 1), which is confirmed by Headhunter's research [33]. It can also be noted that most often digital-instruments are used in such HR areas as: recruitment, training and development, and internal communications. Least of all, digital-tools are used in HR-branding. More than half of the representatives do not plan to digitize the process of compensation and benefits. In general, according to the general situation, it can be noted that the attitude of company representatives to digitalization is gradually changing, and even if the tools were not involved before, their 
implementation is considered possible and planned in the future.

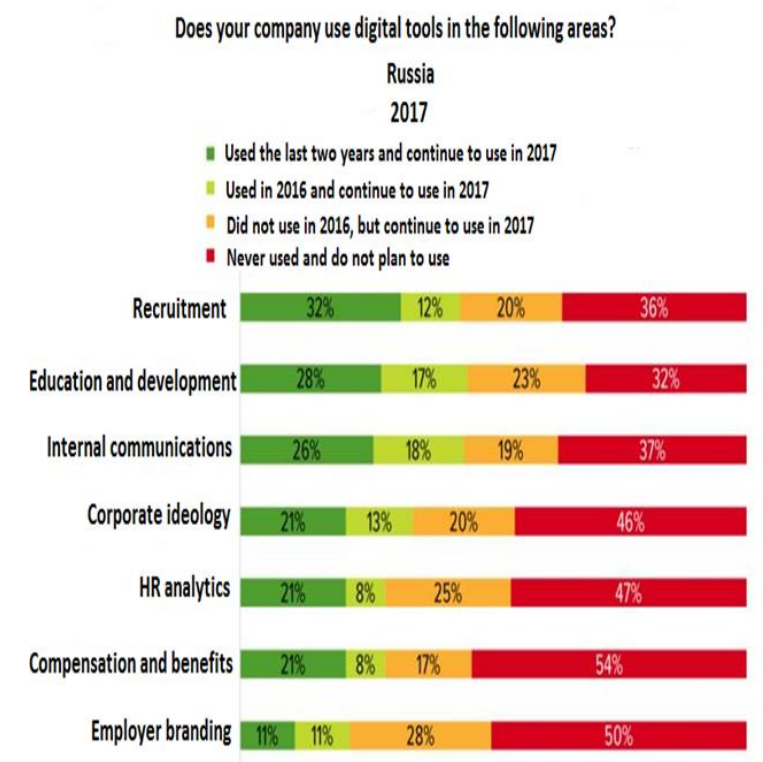

Fig. 1. The degree of use of digital-tools in Russian companies in areas

In order to form a system of requirements for the competencies of a modern employee on a systemic, scientific basis and orient them to the needs of the modern stage of development of society, it is necessary to identify the role of training in this process, and also describe those transformational changes whose implementation will lead to more efficient use of human resources.

The implementation of the paradigm of continuous learning can only be based on the scientific platform of universities. It is universities that not only form professional core competencies, but also ensure their development and transformation [34]. This becomes possible through the implementation of programs of additional and business education.

In the educational system of the Russian Federation, the realization that additional education is necessary has come a long time ago. But to the system of advanced training, professional retraining and business education, the requirements of both quantitative and qualitative nature are increasing. This is due to a number of objective reasons:

- $\quad$ the number of employees who need knowledge not only in their professional field, but also in related areas is increasing;

- multidisciplinary knowledge with a high level of development of professional competencies provides the employee with a high level of his personal competitiveness;

- new types of competencies are emerging based on interdisciplinary knowledge interaction.

Therefore, it is possible to display a set of requirements for a modern employee:

1. Emotional intelligence.

2. Systematic, flexible thinking.
3. Having teamwork skills.

4. High communication skills.

5. Work in conditions of uncertainty and quick decision making.

6. Skills relevant application of IT-technologies in household and professional activities.

7. Interdisciplinary knowledge.

8. Multilingual and multicultural personality.

9. Development of creative potential.

10. Customer focus

11. Lean manufacturing.

12. Ecological thinking.

\section{CONCLUSION}

To date, only a small proportion of employees meet the specified staffing requirements. Mastering these competencies is possible also with the help of digital tools. One of the most appropriate in this regard can be called chat bots.

Chat bots [35] able to develop individual plans for the training and development of each employee. It may also advise special literature or training to obtain the necessary skills. Or conduct a rapid test and advise resources based on the test results.

Chat bot is able to make independent learning more interactive, you can also give feedback through it and conduct testing or certification.

One of these systems provides the ability to implement a chat bot is the Skillaz system. This system allows you to expand the funnel and automate the process of finding and selecting candidates. Based on the profile of the ideal candidate compiled by the head or HR-specialist, the system searches for a suitable candidate among resumes on external sources and websites. Having found a suitable candidate, the system writes a job offer and, if the candidate agrees, then conducts the initial testing. Analyzing the results, the system invites only targeted candidates for an interview, so the recruiter does not spend his time processing thousands of resumes. The advantage of such a system is that all the stages of selection are transparent and controlled in one system. Even after enrollment of a candidate in the state, its effectiveness can be assessed after 6 or 12 months after starting work in the company.

Another platform for employee training is the chat bot Konverbot [36]. This is a kind of personal round-the-clock virtual mentor for each employee, and its functionality includes training, adaptation, and professional development of existing staff. The main environment for such a bot is corporate information systems. The ability to request the necessary information or to be tested on a specific topic is a helper function and allows the employee to keep up with the workplace. Thus, the load on the training center becomes minimal, because the chat bot is able to perform the above functions offline. The advantage is that this platform is able to integrate with existing software (1C, E-Staff), as well as provide a report on each employee in the embedded CRM 
system. Table 2 presents the functions of the Konverbot platform.

Table 2. - The main functions that the chat bot performs

\begin{tabular}{|l|l|}
\hline \multicolumn{1}{|c|}{ Function } & \multicolumn{1}{c|}{ Characteristic } \\
\hline $\begin{array}{l}\text { Tracking for } \\
\text { the adapta- } \\
\text { tion period }\end{array}$ & $\begin{array}{l}\text { The ability to pre-set the date and time when the } \\
\text { bot will initiate a dialogue with the employee. } \\
\text { For example, communication every 3 days with } \\
\text { certain intervals of time and given topics. Or } \\
\text { communication after significant events (training, } \\
\text { certification) }\end{array}$ \\
\hline $\begin{array}{l}\text { Knowledge } \\
\text { base }\end{array}$ & $\begin{array}{l}\text { Downloading the chat bot's useful information on } \\
\text { the enterprise making the employee's adaptation } \\
\text { period easier and more comfortable. This may be } \\
\text { general information about the company, job de- } \\
\text { scription, corporate rules, organizational struc- } \\
\text { ture, contact directory }\end{array}$ \\
\hline $\begin{array}{l}\text { Testing and } \\
\text { certification }\end{array}$ & $\begin{array}{l}\text { Ability to conduct testing on the knowledge of } \\
\text { educational material in the format of interactive } \\
\text { quizzes or conduct a quick survey. This can be a } \\
\text { good preparation of staff for final certification. }\end{array}$ \\
\hline $\begin{array}{l}\text { Analytics } \\
\text { and reports }\end{array}$ & $\begin{array}{l}\text { The control panel, where the results of the effec- } \\
\text { tiveness of the chat bot. A counter that shows the } \\
\text { number of employee interactions with the bot, the } \\
\text { time of each session, the number of hours worked } \\
\text { by the chat bot. }\end{array}$ \\
\hline
\end{tabular}

When introducing such platforms, you can no longer worry about how to convey information to the employee; here the quality of materials and information that you should work on plays a big role.

\section{DISCUSSION}

It can be noted that the state supports and stimulates the development, development and introduction of digital technologies. The Digital Economy program sets a certain trajectory for the development of our society, which affects both business management and forms new milestones of scientific and technological progress.

These changes require the formation of new requirements for human resources management in all sectors without exception, which are relevant in the digital economy. Mastering such skills will allow the employee not only to increase the effectiveness of his professional activity, but also to use the possibilities of implementing an interdisciplinary approach in the implementation of professional competencies.

\section{REFERENCES}

[1] The program "Digital Economy of the Russian Federation" approved by the order of the Government of the Russian Federation dated July 28, 2017 No. 1632-p. GARANT system. - URL: http://base.garant.ru/71734878/38127a69cf2aace7e6dc686e8a4b9579/ \#ixzz5soYa8rfM/ (accessed: 05.05.2019)

[2] Data Economy Russia 2024. - URL: https://dataeconomy.ru/organization (accessed: 10.05.2019))

[3] Crabtree, A., Lodge, T., Colley, J., Greenhalgh, C., Mortier, R., \& Haddadi, H. (2016). Enabling the new economic actor: data protection, the digital economy, and the Databox. Personal and Ubiquitous Computing, 20(6), 947-957.

[4] Levina, A.I., Dubgorn, A.S., Iliashenko, O.Y. Internet of things within the service architecture of intelligent transport systems (2018) Proceedings - 2017 European Conference on Electrical Engineering and Computer Science, EECS 2017, pp. 351-355. DOI: 10.1109/EECS.2017.72
[5] Vonthron, A., Koch, C., \& König, M. (2018). Removing duplicated geometries in IFC models using rigid body transformation estimation and flyweight design pattern. Visualization in Engineering, 6(1), 2.

[6] Scholz, R., Bartelsman, E., Diefenbach, S., Franke, L., Grunwald, A., Helbing, D., ... \& Montag, C. (2018). Unintended side effects of the digital transition: european scientists' messages from a propositionbased expert round table. Sustainability, 10(6), 2001.

[7] Sung, W. (2018, May). Digital innovation and regulatory policy: why does development of digital technology not lead to innovation?. In Proceedings of the 19th Annual International Conference on Digital Government Research: Governance in the Data Age (p. 105). ACM.

[8] Alam, K., Erdiaw-Kwasie, M. O., Shahiduzzaman, M., \& Ryan, B. (2018). Assessing regional digital competence: digital futures and strategic planning implications. Journal of rural studies, 60, 60-69.

[9] Hinings, B., Gegenhuber, T., \& Greenwood, R. (2018). Digital innovation and transformation: An institutional perspective. Information and Organization, 28(1), 52-61.

[10] Schwaferts, D., \& Baldi, S. (2018). Digital Transformation Management and Digital Business Development. In Business Information Systems and Technology 4.0 (pp. 147-159). Springer, Cham.

[11] Ilin, I., Levina, A., Abran, A., Iliashenko, O. (2017). Measurement of enterprise architecture (EA) from an IT perspective: Research gaps and measurement avenues. Paper presented at the ACM International Conference Proceeding Series, Part F131936, 232-243. doi:10.1145/3143434.3143457

[12] Borremans, A.D., Zaychenko, I.M., Iliashenko, O.Yu. Digital economy. IT strategy of the company development (2018) MATEC Web of Conferences, 170, paper no 01034.

[13] Wang, T.a, Gao, S.a, Li, X.bEmail Author, Ning, X.c A meta-networkbased risk evaluation and control method for industrialized building construction projects(Article) Journal of Cleaner Production 2018, PP 552-564.

[14] Ahmed, V., Aziz, Z., Tezel, A., \& Riaz, Z. (2018). Challenges and drivers for data mining in the AEC sector. Engineering, Construction and Architectural Management, 25(11), 1436-1453.

[15] Tsyganov, V.V. Learning Mechanisms in Digital Control of LargeScale Industrial Systems / Proceedings 2018 Global Smart Industry Conference (GloSIC2018). IEEE, 2018. PP. 1-8.

[16] Ilin, I., Iliashenko, O., Iliashenko, V. Approach to the choice of Big Data processing methods in financial sector companies (2018) MATEC Web of Conferences, 193, paper no 05061

[17] Yusupova O.A. Internet banking as a direction of digitalization of banking business: condition, problems, prospects // Financial analytics. Problems and solutions. 2016. №34(316). P.12-15. Business Model Canvas. // Website Canvanizer. - URL: https://canvanizer.com/new/business-model-canvas. - (accessed July, 11, 2019)

[18] Nagibina N.I., Schukina A.A. HR - Digital: Digital technologies in human resource management. // The Internet magazine "SCIENCE" 2017. Volume 9, №1. P.1-17.

[19] Ilin, I., Shirokova, S., Lepekhin, A. IT Solution concept development for tracking and analyzing the labor effectiveness of employees (2018) E3S Web of Conferences, 33, paper no 03007. DOI: 10.1051/e3sconf/20183303007.

[20] Bauer, W., Schlund, S., Vocke, C. Working life within a hybrid world - How digital transformation and agile structures affect human functions and increase quality of work and business performance. Advances in Intelligent Systems and Computing. 2018. 594: PP. 3-10.

[21] Zinke, C., Meyer, K., Friedrich, J. , Reif, L.Digital social learning collaboration and learning in enterprise social networks. Advances in Intelligent Systems and Computing. 2018. 596: PP. 3-11.

[22] Aromaa, S., Leino, S.-P., Reyes-Lecuona, A., (...), van Rhijn, G., Granholm, G.Digital tools to support knowledge sharing and cooperation in high-investment product-services. Advances in Intelligent Systems and Computing. 2018. 606: c.35-246. Meyer P. "Agility Shift: Creating Agile and Effective Leaders, Teams, and Organizations»/// Routledge Academic Magazine. 2015.- 256 p.

[23] Zhu P. «Digital Agility: The Rocky Road from Doing Agile to being Agile» // The BookBaby Magazine. 2016.- 210 p.Digital learning platforms: the future of global education? // Website Training. - 2016. 
- URL: https://trainingmag.com/digital-learning-platforms-futureglobal-education. - (accessed July, 11, 2019)

[24] Shidov A.K., Altudov Y.K., Kazieva B.V., Yakhutlova Z.M., Mashukova M.H. Problems and the Prospects of Training for Providing the Gain of High-Performance Jobs in the Conditions of Cluster Diversification and Digitalization of the Russian Economy Proceedings of the 2018 International Conference "Quality Management, Transport and Information Security, Information Technologies", IT and QM and IS 20185 November 2018, paper no 8525020, PP. 807-810.)

[25] Kankovskaya, A., Kalinina, O., Ilin, I. Economics of transport and sustainable development: Problems of high education in Russia (2018) MATEC Web of Conferences, 239, 08008.

[26] Armstrong M. Strategic human resource management. M., 2002. Budon R. The place of disorder. Criticism of theories of social change. M., 1998.

[27] Gvishiani D.M. Organization and management. M., 1998.

[28] White T. E. The endocrine glands and evolution, No. 3: Os Cementum, Hypsodonty, and Diet. - 1959.

[29] Phyera Humanitarian Portal. - URL: https://psyera.ru/sposobnosti-iprofessionalnye-kompetencii_9001.htm (accessed: 12.05.2019).

[30] Bagaeva, I., Iliashenko, O., Borremans, A. Theoretical and methodological aspects of the competence approach to the evaluation of the organization's personnel // MATEC Web of Conferences. Vol. 193. EDP Sciences, 2018.

[31] Kalinina, O.V., Zaychenko, I.M., Gutman, S.S. Concept of creating innovative mechanism of human resource development in Russia
(2017) Proceedings of the 30th International Business Information Management Association Conference, IBIMA 2017 - Vision 2020: Sustainable Economic development, Innovation Management, and Global Growth, 2017-January, pp. 2708-2719.

[32] Gardner H. Frames of Mind: The theory of Multiple Intelligences. Trans. from English - M .: OOO ID Villame, 2007. - 512 p.

[33] Development of HR processes and the use of digital tools in Russian companies. [Electronic resource]. - URL: https://hhcdn.ru/file/16480569.pdf (accessed: 04.06.2019)

[34] Kozlov, A., Teslya, A. (2017) Human factors for development of corporate internal social investments Portfolio. Advances in Intelligent Systems and Computing, 2017.

[35] Fukolova Y. It's hard to be a bot / Harvard Business Review. Business in the digital age: technology, trends, scenarios - Russia 2018 - 44 p. (accessed: 08.05.2019).

[36] Konvertbot. Creating chat bots for a site with integration into business processes (RPA). [Electronic resource]. - URL: https://bot.konveier.com/ (accessed: 05.04.2019). 